\title{
Ibrutinib in patients with atrial fibrillation - the challenge of thromboembolic prophylaxis
}

\author{
DENISA-CORINA CIUCULETE ${ }^{1,2,3}$, RALUCA ALEXANDRA POPESCU ${ }^{1,2}$, \\ GHEORGHE-ANDREI DAN $1,2,3$
}

\author{
${ }^{1}$ University Hospital Colentina, Bucharest, Romania \\ 2 "Carol Davila" University of Medicine, Bucharest, Romania \\ ${ }^{3}$ CDPC Research Department, Colentina Clinical Hospital, Bucharest, Romania
}

\begin{abstract}
Ibrutinib is a novel drug used in haematological malignancies. Its use is associated with an increased risk of atrial fibrillation (AF), which, in turn, exposes patients to embolic risk, including stroke. Reducing this risk requires anticoagulant therapy which is a matter of concern in the context of the increased bleeding risk of patients with haematological malignancies. In this context the presence of thrombocytopenia related to haematological disorder, ibrutinib-anticoagulants and ibrutinib-platelets interactions contribute to the amplification of the problem. The correct assessment of the thrombosis vs. haemorrhage balance represents a significant challenge for the clinician.

In this paper we discuss practical issues related to anticoagulation in patients treated with ibrutinib and incident AF.
\end{abstract}

Key words: ibrutinib, atrial fibrillation, anticoagulation, thromboembolic prophylaxis, haemorrhagic risk.

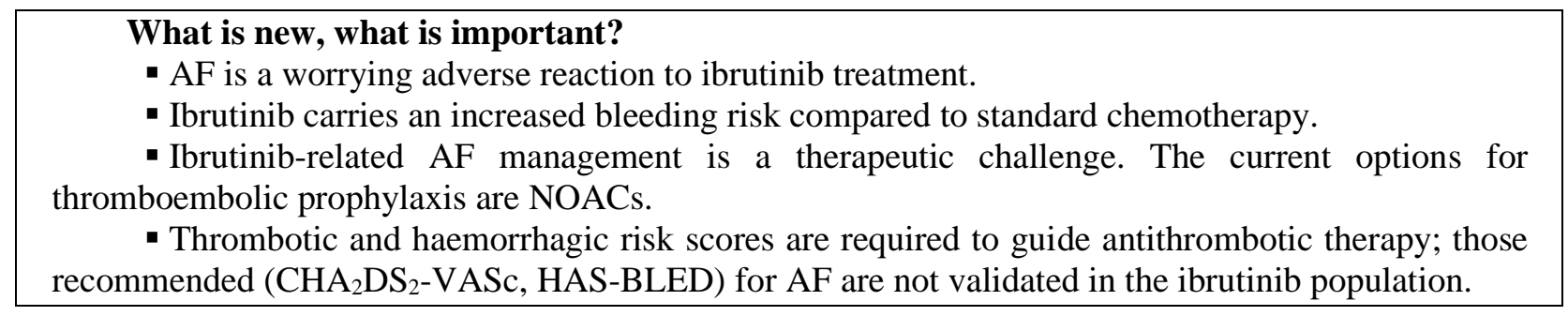

\section{INTRODUCTION}

Ibrutinib is the first bruton kinase inhibitor (BTKi) approved in several B-cell malignancies, including chronic lymphocytic leukemia (CLL), mantle cell lymphoma (MCL), Waldenström's macroglobulinemia and marginal zone lymphoma [1]. Chronic lymphocytic leukemia is the most common type of leukemia, with a median age at diagnosis of 72 years and a ratio 2:1 men: women [2].

AF, hypertension and excessive bleeding are cardiovascular side effects of ibrutinib [3].

$\mathrm{AF}$ is the most common hospitalized rhythm disorder, with an incidence on the rise. It generates a high rate of cardiovascular and cerebrovascular mortality and morbidity, translated into major health care costs [4]. AF is an independent risk factor for thromboembolism [5], which also depends on the presence of demographic, clinical, biological and echocardiographic factors [6]. Validated risk scores for initiating thromboembolic prophylaxis in $\mathrm{AF}$ commonly include advanced age, high blood pressure, heart failure, diabetes, previous stroke, vascular disease, female gender [7]. The use of anticoagulant therapy such as antivitamin $\mathrm{K}$ agents or novel oral anticoagulants (NOACs) significantly reduces embolic risk and mortality (exemplifying "A" from ABC pathway [8]) [6]. Implementation of the $\mathrm{ABC}$ algorithm has improved the prognosis of patients with $\mathrm{AF}$ [8]; in the ibrutinib population the concomitant disease/associated pathology certainly influences general management ("C" - detection and management of Cardiovascular risk factors and Concomitant diseases [8]). Some data indicate that patients with CLL are at higher risk for $\mathrm{AF}$ regardless of ibrutinib use, even after adjusting for age and sex [9].

The incompletely elucidated mechanisms behind the interaction of ibrutinib and 
anticoagulants may generate challenges for the practitioner.

\section{The risk of $\mathrm{AF}$ in neoplastic patients treated with ibrutinib}

Globally, cancer is a risk factor for AF. A cohort of nearly 15,500 patients (REGARDS) reported a $20 \%$ higher adjusted risk of $\mathrm{AF}$ in patients with cancer compared to those without cancer [10]. Moreover, the prognosis of patients with $\mathrm{AF}$ and cancer is worse and the risk of thromboembolism is higher than in those with $\mathrm{AF}$ but without cancer. In addition, the first category of patients has a six-fold higher adjusted risk for heart failure, which also increase the embolic risk $[10,11]$. Despite the growing association between $\mathrm{AF}$ and cancer, there are no specific guidelines for therapeutic behaviour.

$\mathrm{AF}$ is a worrying adverse reaction to ibrutinib treatment, affecting 2 to $16 \%$ of these patients [12]. This incidence is higher than expected in the general population (1-2\% for patients $>65$ years) and cancer patients (4\%) [13].

Several studies have attempted to identify risk factors for AF during ibrutinib therapy. Although limited by the small number of cases, several predictive factors have been reported for the occurrence of AF, including diabetes mellitus, hypertension, prior history of AF [12] and acute infections [14]. Intensifying the cardiological follow-up of this subgroup of patients is an important consequence.

\section{Mechanism of ibrutinib-induced AF}

The mechanism of the ibrutinib-induced AF has not been clarified yet. There are several hypotheses trying to explain this association. The most commonly mentioned mechanism is related to phosphoinositide-3-kinase-protein kinase B/Akt (PI3K-PKB/Akt) inhibition by ibrutinib. PI3K-Akt plays a role in cardiac protection under stress conditions, being an intracellular signalling pathway targeting multiple cellular functions, including cell proliferation and survival, angiogenesis, increased metabolism $[13,15,16]$. The PI3K inhibition could result in AF by activation of late sodium channels [17]. This may lead to prolongation of cardiac action potential duration (APD) and so increased vulnerability to early depolarization that in turn may increase the risk of both atrial and ventricular arrhythmias [3]. In general, increasing and not decreasing APD favors AF [18], but the early afterdepolarization promotion by ibrutinib may increase the possibility of triggering AF.

It has been observed that decreased cardiac PI3K activity increases the susceptibility of AF in mice $[19,20]$. Also, human heart samples from patients with and without AF were compared and reduced cardiac PI3K activity was observed in those with AF [19, 20]. Moreover, in an experimental model of rat myocytes exposure to ibrutinib resulted in less PI3K expression and therefore may predispose to AF [21]. However, these findings cannot be extrapolated to humans, their applicability being questionable. Moreover, there is no evidence confirming inhibition of PI3K by ibrutinib in vitro or in vivo [15]. As of yet, no evidence of ibrutinib's functional effect on cardiac myocytes has been demonstrated [15].

Other potential mechanisms refer to structural remodelling and calcium handling disorders in the atrium [22] or to reduced activity in tyrosine kinase pathways other than PI3K-Akt [23].

The underlying mechanisms remain unclear, further research being needed to elucidate them.

\section{The haemorrhagic risk in patients treated with ibrutinib}

Ibrutinib, an effective therapeutic agent for multiple B-cell mediated lymphoproliferative disorders, carries an increased bleeding risk compared to standard chemotherapy and is also associated with an increased risk of $\mathrm{AF}$ which often requires anticoagulation [24]. This clinical situation leads to complex decisions regarding stroke vs. bleeding risk, for which evidence-based data is currently lacking.

In clinical trials ibrutinib has been found to be associated with approximately 50\% risk of bleeding [25], the majority of these events being low grade such as subcutaneous or mucosal bleeding, including epistaxis, haematuria, petechial bleeding, contusions, or ecchymosis [24]. Major haemorrhage has been reported between 1 and $10 \%$ in major trials [25] with fatal bleeding occurring in less than $1 \%$ of patients $[26,27]$.

\footnotetext{
Mechanisms of ibrutinib-induced haemorrhagic risk

The mechanisms behind ibrutinib's increased bleeding risk are manifold, including Bruton's tyrosine kinase (BTK) and other intracellular molecules inhibition, ibrutinib-induced thrombo-
} 
cytopenia or enhancement of CLL-induced platelet function impairment [28].

Ibrutinib inhibits irreversibly BTK and related TEC (tyrosine expressed in hepatocellular carcinoma) kinases [29], both molecules being involved in downstream signalling of collagen receptor glycoprotein VI (GPVI) and C-type lectin-like receptor 2 (CLEC-2). GPVI is responsible for platelet activation [30]. CLEC-2 is a platelet transmembrane receptor which enhances thrombus stability after platelet adhesion to damaged endothelium [28].

Ibrutinib also interferes with platelet GPIbmediated platelet functions. GPIb binds to von Willebrand factor, this interaction leading to the attachment of platelets to the damaged vascular wall and stimulating multiple platelet pathways and platelet cytoskeletal reorganization. BTK is essential in von Willebrand factor - induced signalling and GPIb-dependent thrombus formation [24, 31]. Therefore, BTK inhibition increases haemorrhagic risk. Also, the inhibitory effect of ibrutinib on von Willebrand factor GPIb interactions may explain the bleeding mostly in the microvasculature where shear stress is elevated [32].

Ibrutinib also inhibits platelet adhesion to fibrinogen, blocking the interaction fibrinogen integrin $\alpha I I b \beta 3$, which involves BTK [33]. Physiologically fibrinogen binds to this integrin on the platelet membrane, triggering platelet adhesion, spreading and clot retraction [28].

Furthermore, patients with CLL have mild defects of platelet function which can be exacerbated by ibrutinib via inhibition of collagendependent platelet aggregation [34]. Adding, patients with CLL often have significant thrombocytopenia and ibrutinib also causes cytopenias, including thrombocytopenia [15].

Baseline abnormalities in platelet function (activation, adhesion and aggregation), combined with drug-related effects, boost bleeding risk in patients on ibrutinib.

Considering the effects on platelets, the question arises whether ibrutinib could confer some cardiovascular protective properties. To date, there is no data regarding the effect of ibrutinib on the thromboembolic risk of AF [35]. It appears that after mechanical arterial injury, GPVI inhibition could reduce thrombotic risk, protecting against platelet adhesion, thrombus extension, as well as against leukocyte recruitment and neointimal hyperplasia [36, 37]. Also,
GPVI inhibition may limit plaque-induced thrombus formation [24, 38, 39]. In vascular disease, inhibition of the von-Willebrand-GPIb axis is a potential antithrombotic target [40]. Despite the interaction of ibrutinib with GPVI and with von Willebrand factor-GPIb axis, there are insufficient data to support the possible efficacy of ibrutinib in reducing cardiovascular risk [24].

Ibrutinib therapy in patients with B cell malignancy results in high response rates and long progression-free survival. Despite the haemorrhagic risk, especially when combined with an antithrombotic, its continuation remains important [14].

\section{Anticoagulation in $\mathrm{AF}$ patients receiving ibrutinib}

Because of the increased haemorrhagic risk of ibrutinib treated patients, the decision to anticoagulate is challenging.

The decision to anticoagulate the patient with $\mathrm{AF}$ is based on the $\mathrm{CHA}_{2} \mathrm{DS}_{2}-\mathrm{VASc}$ score (congestive heart failure/left ventricular dysfunction, hypertension, age $\geq 75$ years ( 2 points), diabetes, stroke ( 2 points), vascular disease, age 65-74 years, and female sex category), which is the best validated scale for stroke risk in patients with AF. The European Society of Cardiology recommends initiation of anticoagulant therapy in men with a $\mathrm{CHA}_{2} \mathrm{DS}_{2}$ VASc score $\geq 1$ and in women with a score $\geq 2$ [8]. For patients with a $\mathrm{CHA}_{2} \mathrm{DS}_{2}-\mathrm{VASc}$ score of 0 or 1 for women, no antithrombotic therapy is required [8].

However, $\mathrm{CHA}_{2} \mathrm{DS}_{2}-\mathrm{VASc}$ was not evaluated in patients on ibrutinib or in patients with pathology manageable by ibrutinib [41]. Moreover, the neoplastic context increases thrombotic risk depending of cancer type [41, 42]. At this time, there is no specific score to help establish the anticoagulation indication in patients with $\mathrm{AF}$ treated with ibrutinib.

Estimation of haemorrhagic risk in patients treated with oral anticoagulants can be performed using several scores.

Among all, the HAS-BLED score was the most validated and is recommended in patients with $\mathrm{AF}$ $[42,8]$. However, the HAS-BLED score does not take into account the platelet count, the functional status of platelets and the therapy with ibrutinib which, as shown above, increases the risk of bleeding. So, this score underestimates the haemorrhagic risk [41]. 
Another useful tool for monitoring and managing the bleeding tendency could be the quantitative assessment of RIPA (ristocetininduced platelet aggregation), which might thereby increase the prediction of bleeding [43], but this this assay has not been validated in $\mathrm{AF}$ patients on oral anticoagulant.

Although in the general AF population a HASBLED score above 3 does indicate an increased bleeding risk however it does not contraindicate anticoagulant therapy, in patients on ibrutinib there are several different recommendations, most of them based on expert opinion [44]. It is recommended not to anticoagulate the patient with ibrutinib-related $\mathrm{AF}$ if the $\mathrm{CHA}_{2} \mathrm{DS}_{2}-\mathrm{VASc}$ score is less than or equal to HAS-BLED score [44]. If the $\mathrm{CHA}_{2} \mathrm{DS}_{2}-\mathrm{VASc}$ score is higher than HASBLED score the recommendation is to administer an anticoagulant, preferring NOAC (nonantivitamin $\mathrm{K}$ anticoagulant) over VKA (antivitamin $\mathrm{K}$ anticoagulant) and to consider alternative anti-lymphoproliferative disorder treatment options $[14,44]$. This last recommenddation could compromise progression-free survival and overall survival in these patients. Withholding ibrutinib when atrial fibrillation develops does not seem to prompt a higher resolution rate of the rhythm disorder [14].

Forgoing anticoagulation for $\mathrm{AF}$ may be a reasonable option even if the $\mathrm{CHA}_{2} \mathrm{DS}_{2}$-VASc score is $\geq 2$ in patients on ibrutinib and a high risk of bleeding, in patients with limited lifeexpectancy ( $<12$ months) [41].

Control of modifiable risk factors for bleeding as hypertension, alcohol consumption or comedication predisposing to bleeding is mandatory [45].

Ultimately, the anticoagulation decision should be made by a multidisciplinary team consisting of cardiologist, haematologist/ oncologist with the patient fully informed about the thrombotic and haemorrhagic risks [44].

\section{Oral anticoagulants use in $\mathrm{AF}$ patients treated with ibrutinib}

The standard options for thromboembolic prophylaxis in AF are NOACs (novel oral anticoagulants) and anti-vitamin $\mathrm{K}$ anticoagulants [45].

Patients on warfarin were excluded from most trials with ibrutinib because of the initial observations of major bleeding. [24] To date, there is a paucity of safety data regarding concomitant use of these drugs [35]. Currently, ibrutinib is contraindicated in patients on anti-vitamin $\mathrm{K}$ anticoagulants, but NOACs were allowed in pivotal ibrutinib trials [46].

Ibrutinib is metabolized in the liver, primarily by cytochromes P450 and 3A4 (CYP3A4) [24] and to a lesser extent by CYP2D6 [47], to active metabolite. Also, ibrutinib is an inhibitor of the transporter P-glycoprotein (P-gp), but this inhibition is not fully established in vivo. However, the increased risk of bleeding in these patients is not caused by the increased plasma levels of the anticoagulant but by the additional risk generated by ibrutinib [28].

NOACs have less drug interactions than warfarin. Many drug interactions with NOACs occur in the intestine, involving the P-gp, particularly for dabigatran. All NOACs are substrates of the P-gp, which as previously mentioned, is inhibited by ibrutinib. Rivaroxaban and apixaban are metabolised extensively by CYP3A4 [48], whereas dabigatran and edoxaban are not [49].

Therefore, ibrutinib may increase the plasma concentration of these anticoagulants and thus the risk of bleeding.

Evidence from drug-drug interactions and antiplatelet effects of ibrutinib show that thromboembolic prophylaxis in ibrutinib-related $\mathrm{AF}$ is challenging. Expert recommendations are limited as they are based on small scale, retrospective studies. Options for anticoagulant therapy are oral factor $X_{a}$ inhibitors that have clinically insignificant CYP3A4 interactions with ibrutinib, while the use of warfarin and low-molecular-weight heparin is recommended to be avoided [50].

Regarding the doses to be used, currently lowdoses of oral factor $X_{a}$ inhibitors are recommended for the first 7-10 days from therapy initiation, with the possibility of further increase depending on the patient's response [50]. As ibrutinib is a P-glycoprotein inhibitor and dabigatran (especially $150 \mathrm{mg}$ b.i.d) is a potent substrate for P-gp, their association is discouraged [50].

Current anticoagulant therapy recommenddations for thromboembolic prophylaxis in ibrutinib-related AF, in patients with normal renal function, in the absence of other drug-drug interactions are summarized in Table 1. Furthermore, temporary dosage reduction but not withdrawing ibrutinib may be considered when initiating a NOAC [29]. 
Table 1

Anticoagulant therapy in ibrutinib - related AF [50, 29]

\begin{tabular}{|c|c|c|}
\hline $\begin{array}{c}\text { Antithrombotic } \\
\text { therapy }\end{array}$ & Initial dose & Maintenance dose \\
\hline Apixaban & $2,5 \mathrm{mg}$ b.i.d & $5 \mathrm{mg}$ b.i.d \\
\hline Rivaroxaban & $15 \mathrm{mg}$ o.d & $20 \mathrm{mg}$ o.d \\
\hline Edoxaban & $30 \mathrm{mg} \mathrm{o.d}$ & $60 \mathrm{mg}$ o.d \\
\hline
\end{tabular}

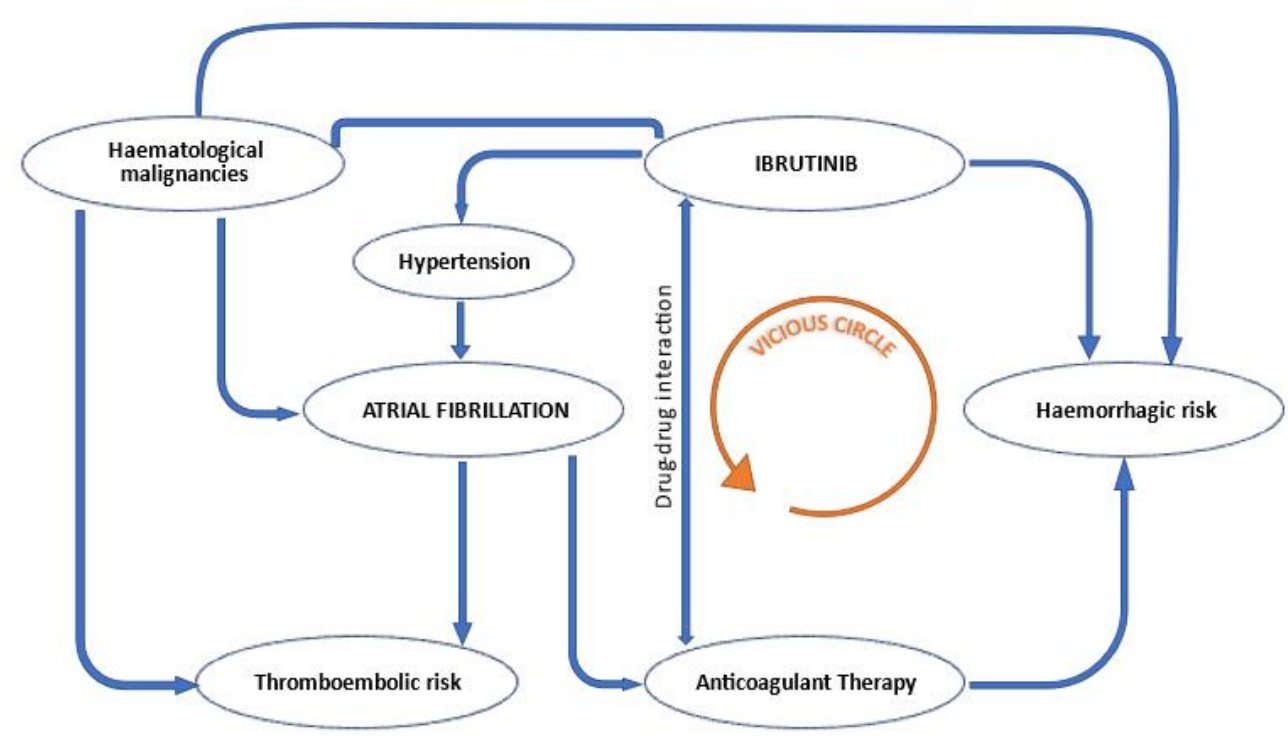

Figure 1. Interrelation ibrutinib - AF - haemorrhage.

\section{Alternatives to anticoagulant therapy}

In patients who cannot receive anticoagulant therapy, left atrial appendage occlusion should be considered [41]. Special devices are approved for reducing long-term anticoagulation requirements in AF patients [51]. However, a major disadvantage is the need to combine anticoagulant with antiplatelet therapy during endothelialisation process into the appendage, to prevent thrombus formation on the device itself [52]. In addition, antithrombotic therapy after occlusion has not been yet evaluated in randomized trials [8]. If patients cannot receive antiplatelet therapy, the options to consider are epicardial catheter approach or thoracoscopic clipping of the left atrial appendage [8]. However, if there is an absolute contraindication for anticoagulation, according to the ASAP study, post-procedural dual antiplatelet therapy (aspirin plus clopidogrel) could be used for 6 months or even for 1 to 3 months for patients at very high risk of bleeding [53]. More studies are needed to test the outcomes of left atrial appendage occlusion in such patients.

\section{CONCLUSION}

The optimal thromboembolic prevention in AF patient under chemotherapy is challenging.

Ibrutinib, used in chronic lymphocytic leukemia, mantle cell lymphoma, Waldenström's macroglobulinemia and marginal zone lymphoma is associated with increased haemorrhagic risk and AF rising yet unsolved therapeutic issues.

The ibrutinib-related AF anticoagulation decision does not yet have extensive scientific 
support. The classic risk scores from AF $\left(\mathrm{CHA}_{2} \mathrm{DS}_{2}-\mathrm{VASc}\right.$ and HAS-BLED) are used without being validated in this population. Thus, the anticoagulation of patients with a $\mathrm{CHA}_{2} \mathrm{DS}_{2}-\mathrm{VASc}$ score higher than HAS-BLED is preferred. However, if the bleeding risk is very high, left atrial appendage occlusion may be considered. The therapeutic options are limited to NOACs, especially apixaban, rivaroxaban and edoxaban, with doses adapted to the neoplastic context. NOACs are often a safe alternative to antivitamin $\mathrm{K}$ anticoagulants in cancer associated AF [41].

Stopping or replacing ibrutinib may not be profitable for patients with haematological conditions. Therapeutic decisions must be individualized and patient-centered, with an accurate estimation of benefits. The Cardiologist-Hematologist team [54] should optimize decisions by integrating stroke risk from AF with the cancer context, response to treatment and prognosis.

\begin{abstract}
Ibrutinibul este un medicament nou folosit in patologii maligne hematologice. Este asociat cu un risc crescut de apariție a fibrilației atriale, care, la rândul ei, expune pacienții la risc embolic, inclusiv accident vascular cerebral. Reducerea acestui risc necesită terapie anticoagulantă, care constituie o problemă în contextul riscului hemoragic crescut al pacienților cu patologie malignă hematologică. Prezența trombocitopeniei din cadrul patologiei hematologice, interacțiunile ibrutinib-anticoagulante și ibrutinib-trombocite contribuie la amplificarea problemei. Aprecierea corectă a balanței tromboză vs. hemoragie reprezintă o provocare semnificativă pentru clinician. În acest articol discutăm provocările practice legate de anticoagulare la pacienții tratați cu ibrutinib și având fibrilație atrială.
\end{abstract}

Correspondence to: Raluca Alexandra Popescu, MD, PhD, Colentina Hospital, 19-21 Stefan Cel Mare 19-21 Road, Postal code 020125, Bucharest Romania, e-mail: raluca.popescu@umfcd.ro

Conflict of interest disclosure: The authors declare that there are no conflicts of interest.

\title{
REFERENCES
}

1. CHLOE PEK SANG TANG, JULIE MCMULLEN, CONSTANTINE TAM. Cardiac side effects of bruton tyrosine kinase (BTK) inhibitors. Leuk. Lymphoma 2018;59(7):1554-1564.

2. MICHAEL HALLEK, TAIT D. SHANAFELT, BARBARA EICHHORST. Chronic lymphocytic leukaemia. Lancet 2018;391(10129):1524-1537.

3. SARJU GANATRA, AJAY SHARMA, SACHIN SHAH, GHULAM M. CHAUDHRY, DAVID T. MARTIN, TOMAS G. NEILAN, et al. Ibrutinib-Associated Atrial Fibrillation. JACC Clin. Electrophysiol. 2018;4(12):1491-1500.

4. FRANCESCA PISTOIA, SIMONA SACCO, CINDY TISEO, DIANA DEGAN, RAFFAELE ORNELLO, ANTONIO CAROLEI. The Epidemiology of Atrial Fibrillation and Stroke. Cardiol. Clin. 2016;34(2):255-268.

5. MICHAEL HUGHES, GREGORY Y.H. LIP. Stroke and thromboembolism in atrial fibrillation: A systematic review of stroke risk factors, risk stratification schema and cost effectiveness data. Thromb. Haemost. 2008;99(2):295-304.

6. RON PISTERS, DEIRDRE A. LANE, FRANCISCO MARIN, A. JOHN CAMM, GREGORY Y.H. LIP. Stroke and Thromboembolism in Atrial Fibrillation - Systematic Review of Stroke Risk Factors and Risk Stratification Schema - Circ. J. 2012;76(10):2289-2304.

7. WEN GEN ZHU, QIN MEI XIONG, KUI HONG. Meta-analysis of CHADS2 versus CHA2DS2-VASc for predicting stroke and thromboembolism in atrial fibrillation patients independent of anticoagulation. Texas Hear. Inst. J. 2015;42(1):6-15.

8. GERHARD HINDRICKS, TATJANA POTPARA, NIKOLAOS DAGRES, ELENA ARBELO, JEROEN J BAX, CARINA BLOMSTRÖM-LUNDQVIST, et al. 2020 ESC Guidelines for the diagnosis and management of atrial fibrillation developed in collaboration with the European Association for Cardio-Thoracic Surgery (EACTS). Eur. Heart J. 2021;42(5):373-498.

9. TAIT D. SHANAFELT, SAMEER A. PARIKH, PETER A. NOSEWORTHY, VALENTIN GOEDE, KARI G. CHAFFEE, JASMIN BAHLO, et al. Atrial fibrillation in patients with chronic lymphocytic leukemia (CLL). Leuk. Lymphoma 2017;58(7):1630-1639.

10. AVIRUP GUHA, AMIT K. DEY, HANI JNEID, JAVIER PINILLA IBARZ, DANIEL ADDISON, MICHAEL FRADLEY. Atrial Fibrillation in the Era of Emerging Cancer Therapies. Eur. Heart J. 2019;40(36):3007-3010. 
11. FAISAL RAHMAN, DARAE KO, EMELIA J. BENJAMIN. Association of atrial fibrillation and cancer. JAMA Cardiol. 2016;1(4):384-386.

12. TRACY E. WICZER, LAUREN B. LEVINE, JESSICA BRUMBAUGH, JESSICA COGGINS, QIUHONG ZHAO, AMY S. RUPPERT, et al. Cumulative incidence, risk factors, and management of atrial fibrillation in patients receiving ibrutinib. Blood Adv. 2017;1(20):1739-1748.

13. DEBORAH M. STEPHENS, JOHN C. BYRD. How I manage ibrutinib intolerance and complications in patients with chronic lymphocytic leukemia. Blood 2019;133(12):1298-1307.

14. IRIS DE WEERDT, SUZANNE M. KOOPMANS, ARNON P. KATER, MICHEL VAN GELDER. Incidence and management of toxicity associated with ibrutinib and idelalisib: A practical approach. Haematologica 2017;102(10):1629-1639.

15. BRONWYN C. THORP, XAVIER BADOUX. Atrial fibrillation as a complication of ibrutinib therapy: clinical features and challenges of management. Leuk. Lymphoma 2018;59(2):311-320.

16. BRIAN A HEMMINGS, DAVID F RESTUCCIA. PI3K-PKB / Akt Pathway 2016; 1-4.

17. MARKUS C. STÜHLINGER, ANSGAR WELTERMANN, PHILIPP STABER, DANIEL HEINTEL, THOMAS NÖSSLINGER, MICHAEL STEURER. Recommendations for ibrutinib treatment in patients with atrial fibrillation and/or elevated cardiovascular risk. Wien. Klin. Wochenschr. 2019;

18. GARY TSE. Mechanisms of cardiac arrhythmias. J. Arrhythmia 2016;32(2):75-81

19. LYNETTE PRETORIUS, XIAO JUN DU, ELIZABETH A. WOODCOCK, HELEN KIRIAZIS, RUBY C.Y. LIN, SILVANA

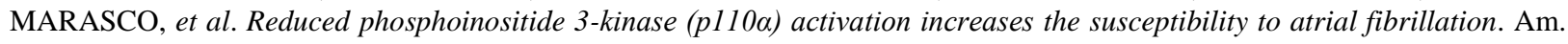
J. Pathol. 2009;175(3):998-1009.

20. JULIE R MCMULLEN, ESTHER J H BOEY. Correspondence To the editor: Ibrutinib increases the risk of atrial fibrillation, potentially through inhibition of cardiac. Blood 2014;124(25):3829-3831.

21. ROBERT JANKOV, KEITH TANSWELL. CORRESPONDENCE: Response. Pediatr. Res. 2003;53(1):200.

22. LE JIANG, LINLING LI, YANFEI RUAN, SONG ZUO, XIAOYAN WU, QIANQIAN ZHAO, et al. Ibrutinib promotes atrial fibrillation by inducing structural remodeling and calcium dysregulation in the atrium. Hear. Rhythm 2019;16(9):1374-1382

23. TRACY E WICZER, LAUREN B LEVINE, JESSICA BRUMBAUGH, JESSICA COGGINS, QIUHONG ZHAO, AMY S RUPPERT, et al. Cumulative incidence, risk factors, and management of atrial fibrillation in patients receiving ibrutinib. Blood Adv. 2017;1(20):1739-1748.

24. J. J. SHATZEL, S. R. OLSON, D. L. TAO, O. J.T. MCCARTY, A. V. DANILOV, T. G. DELOUGHERY. Ibrutinib-associated bleeding: pathogenesis, management and risk reduction strategies. J. Thromb. Haemost. 2017;15(5):835-847.

25. SEMRA PAYDAS. Management of adverse effects/toxicity of ibrutinib. Crit. Rev. Oncol. Hematol. $2019 ; 136$ (August 2018):56-63.

26. ASHER CHANAN-KHAN, PAULA CRAMER, FATIH DEMIRKAN, GRAEME FRASER, RODRIGO SANTUCCI SILVA, SEBASTIAN GROSICKI, et al. Ibrutinib combined with bendamustine and rituximab compared with placebo, bendamustine, and rituximab for previously treated chronic lymphocytic leukaemia or small lymphocytic lymphoma (HELIOS): A randomised, double-blind, phase 3 study. Lancet Oncol. 2016;17(2):200-211.

27. JOHN C BYRD, RICHARD R FURMAN, STEVEN E COUTRE, JAN A BURGER, KRISTIE A BLUM, MORTON COLEMAN, et al. $l$ ve and previously treated patients with CLL and SLL receiving single-agent ibrutinib. Blood 2015;125(16):2497-2507.

28. CARLOS AGUILAR. Ibrutinib-related bleeding: Pathogenesis, clinical implications and management. Blood Coagul. Fibrinolysis 2018;29(6):481-487.

29. GIUSEPPE BORIANI, PAOLO CORRADINI, ANTONIO CUNEO, ANNA FALANGA, ROBIN FOÀ, GIANLUCA GAIDANO, et al. Practical management of ibrutinib in the real life: Focus on atrial fibrillation and bleeding. Hematol. Oncol. 2018;36(4):624-632.

30. RACHEL A. RIGG, JOSEPH E. ASLAN, LAURA D. HEALY, MICHAEL WALLISCH, MARISA L.D. THIERHEIMER, CASSANDRA P. LOREN, et al. Oral administration of bruton's tyrosine kinase inhibitors impairs GPVI-mediated platelet function. Am. J. Physiol. - Cell Physiol. 2016;310(5):C373-C380.

31. L. S. QUEK, J. BOLEN, S. P. WATSON. A role for Bruton's tyrosine kinase (Btk) in platelet activation by collagen. Curr. Biol. 1998;8(20):1137-1140.

32. MARIE LEVADE, ELODIE DAVID, CÉDRIC GARCIA, PIERRE ALEXANDRE LAURENT, SARAH CADOT, ANNE SOPHIE MICHALLET, et al. Ibrutinib treatment affects collagen and von Willebrand factor-dependent platelet functions. Blood 2014;124(26):3991-3995.

33. ALESSANDRA SORIANI, B. MORAN, M. DE VIRGILIO, T. KAWAKAMI, A. ALTMAN, C. LOWELL, et al. A role for PKC $\theta$ in outside-in $\alpha I I b \beta 3$ signaling. J. Thromb. Haemost. 2006;4(3):648-655.

34. ANDREW H. LIPSKY, MOHAMMED Z.H. FAROOQUI, XIN TIAN, SABRINA MARTYR, ANN M. CULLINANE, KHANH NGHIEM, et al. Incidence and risk factors of bleeding-related adverse events in patients with chronic lymphocytic leukemia treated with ibrutinib. Haematologica 2015;100(12):1571-1578.

35. KHAI LI CHAI, GAIL ROWAN, JOHN F. SEYMOUR, KATE BURBURY, DENNIS CARNEY, CONSTANTINE S. TAM. Practical recommendations for the choice of anticoagulants in the management of patients with atrial fibrillation on ibrutinib. Leuk. Lymphoma 2017;58(12):2811-2814.

36. HAKUOH KONISHI, YOUICHI KATOH, NORIHIDE TAKAYA, YUJI KASHIWAKURA, SEIGO ITOH, CHISEI RA, et al. Platelets activated by collagen through immunoreceptor tyrosine-based activation motif play pivotal role in initiation and generation of neointimal hyperplasia after vascular injury. Circulation 2002;105(8):912-916.

37. STEFFEN MASSBERG, MEINRAD GAWAZ, SABINE GRÜNER, VALERIE SCHULTE, ILDIKO KONRAD, DIETLIND ZOHLNHÖFER, et al. A crucial role of glycoprotein VI for platelet recruitment to the injured arterial wall in vivo. J. Exp. Med. 2003;197(1):41-49. 
38. JUDITH M.E.M. COSEMANS, MARIJKE J.E. KUIJPERS, CHRISTELLE LECUT, SARAH T.B.G. LOUBELE, SYLVIA HEENEMAN, MARTINE JANDROT-PERRUS, et al. Contribution of platelet glycoprotein VI to the thrombogenic effect of collagens in fibrous atherosclerotic lesions. Atherosclerosis 2005;181(1):19-27.

39. ARMIN J. REININGER, ISABELL BERNLOCHNER, SANDRA M. PENZ, CATHERINE RAVANAT, PETER SMETHURST, RICHARD W. FARNDALE, et al. A 2-Step Mechanism of Arterial Thrombus Formation Induced by Human Atherosclerotic Plaques. J. Am. Coll. Cardiol. 2010;55(11):1147-1158.

40. FREDERIK DENORME, SIMON F. DE MEYER. The VWF-GPib axis in ischaemic stroke: Lessons from animal models. Thromb. Haemost. 2016;116(4):597-604.

41. ISAAC B. RHEA, ALEXANDER R. LYON, MICHAEL G. FRADLEY. Anticoagulation of Cardiovascular Conditions in the Cancer Patient: Review of Old and New Therapies. Curr. Oncol. Rep. 2019;21(5):1-11.

42. YUTAO GUO, HANG ZHU, YUNDAI CHEN, GREGORY Y.H. LIP. Comparing Bleeding Risk Assessment Focused on Modifiable Risk Factors Only Versus Validated Bleeding Risk Scores in Atrial Fibrillation. Am. J. Med. 2018;131(2):185-192.

43. L. KAZIANKA, C. DRUCKER, C. SKRABS, W. THOMAS, T. MELCHARDT, S. STRUVE, et al. Ristocetin-induced platelet aggregation for monitoring of bleeding tendency in CLL treated with ibrutinib. Leukemia 2017;31(5):1117-1122.

44. ALAINA VRONTIKIS, JESSICA CAREY, JEFFREY A. GILREATH, AHMAD HALWANI, DEBORAH M. STEPHENS, JOHN W. SWEETENHAM. Proposed algorithm for managing Ibrutinib-related atrial fibrillation. Oncol. (United States) 2016;

45. P. KIRCHHOF, STEFANO BENUSSI, DIPAK KOTECHA, ANDERS AHLSSON, DAN ATAR, BARBARA CASADEI, et al. 2016 ESC Guidelines for the management of atrial fibrillation developed in collaboration with EACTS. Eur. Heart J. 2016;37(38):2893-2962.

46. MICHAEL L. WANG, HUN LEE, HUBERT CHUANG, NICOLAUS WAGNER-BARTAK, FREDERICK HAGEMEISTER, JASON WESTIN, et al. Ibrutinib in combination with rituximab in relapsed or refractory mantle cell lymphoma: A singlecentre, open-label, phase 2 trial. Lancet Oncol. 2016;17(1):48-56.

47. JENNIFER R. BROWN. How I treat CLL patients with ibrutinib. Blood 2018;131(4):379-386.

48. JOHN LEONARD FITZGERALD, LAURENCE GUY HOWES. Drug Interactions of Direct-Acting Oral Anticoagulants. Drug Saf. 2016;39(9):841-845.

49. ALLISON E. BURNETT, CHARLES E. MAHAN, SARA R. VAZQUEZ, LYNN B. OERTEL, DAVID A. GARCIA, JACK ANSELL. Guidance for the practical management of the direct oral anticoagulants (DOACs) in VTE treatment. J. Thromb. Thrombolysis 2016;41(1):206-232.

50. ZAIN AL-JAMMALI, BRENT BECKNER, JOSEPH BUBALO. Ibrutinib-Related Atrial Fibrillation: An Anticoagulant Challenge. JHOPonline.com 1 J. Hematol. Oncol. Pharm. 2019;9(2):47-50.

51. FREDERICK A. MASOUDI, HUGH CALKINS, CLIFFORD J. KAVINSKY, JOSEPH P. DROZDA, PHILLIP GAINSLEY, DAVID J. SLOTWINER, et al. 2015 ACC/HRS/SCAI Left Atrial Appendage Occlusion Device Societal Overview. J. Am. Coll. Cardiol. 2015;66(13):1497-1513.

52. DAVID R. HOLMES, SAIBAL KAR, MATTHEW J. PRICE, BRIAN WHISENANT, HORST SIEVERT, SHEPHAL K. DOSHI, et al. Prospective randomized evaluation of the watchman left atrial appendage closure device in patients with atrial fibrillation versus long-term warfarin therapy: The PREVAIL trial. J. Am. Coll. Cardiol. 2014;64(1):1-12.

53. VIVEK Y. REDDY, SVEN MÖBIUS-WINKLER, MARC A. MILLER, PETR NEUZIL, GERHARD SCHULER, JENS WIEBE, et al. Left atrial appendage closure with the watchman device in patients with a contraindication for oral anticoagulation: The ASAP study (ASA plavix feasibility study with watchman left atrial appendage closure technology). J. Am. Coll. Cardiol. 2013;61(25):2551-2556.

54. TERESA LÓPEZ-FERNÁNDEZ, ANA MARTÍN GARCÍA, ANA SANTABALLA BELTRÁN, ÁNGEL MONTERO LUIS, RAMÓN GARCÍA SANZ, PILAR MAZÓN RAMOS, et al. Cardio-Onco-Hematology in Clinical Practice. Position Paper and Recommendations. Rev. Esp. Cardiol. 2017;70(6):474-486.

Received 13th March 2021 